Original research article

\title{
Social support in the education of patients with cardiovascular diseases: the situation in the Czech Republic
}

\author{
Lenka Šedová $^{1 *}$, Valérie Tóthová ${ }^{1}$, Věra Olišarová ${ }^{1}$, Sylva Bártlová ${ }^{1}$, Ivana Chloubová ${ }^{1}$, \\ Helena Michálková ${ }^{1}$, Marie Trešlová ${ }^{1}$, Radka Prokešová ${ }^{2}$, Kristýna Toumová ${ }^{1}$, Věra Adámková ${ }^{3}$ \\ ${ }^{1}$ University of South Bohemia in České Budějovice, Faculty of Health and Social Sciences, Institute of Nursing, Midwifery, and Emergency Care, \\ České Budějovice, Czech Republic \\ 2 University of South Bohemia in České Budějovice, Faculty of Health and Social Sciences, Institute of the Humanities in Nursing Professions, \\ České Budějovice, Czech Republic \\ ${ }^{3}$ Institute for Clinical and Experimental Medicine, Preventive Cardiology Department, Prague, Czech Republic
}

\begin{abstract}
The incidence of cardiovascular disease is linked to the risk factors of lifestyle. Traditional influences are smoking, diet, physical activity and psychosocial factors. Psychosocial factors include low socio-economic status, lack of social support, work-related stress and the state or type of family life, depression and anxiety, and hostility.

The aim of this study was to demonstrate the connection of the views on selected psychosocial factors of cardiovascular diseases with selected sociodemographic characteristics. A quantitative method using quantitative interviews was used to achieve the objectives. In total, 1,992 persons aged 40 years and older were addressed. The set was representative of age, gender, and residence. The information obtained was subjected to statistical analysis and the rate of dependence was assessed by the chi-2 test, the $t$-test and the analysis of the test.

The results show that in prevention the doctors are focused on obtaining information about the employment of their patients, the patient's lifestyle and how the diagnosed cardiovascular disease affects the normal life of patients. Less often, in practice, questions on socio-economic factors are found. In most questions, there was a significant link with age, employment and family status. Positive questions were more often answered by respondents over the age of 60 , widowed respondents and respondents in disability or retirement age. This may be related to targeted interventions for these vulnerable groups of patients. For most respondents, the family is a foothold of lifestyle change.
\end{abstract}

Keywords: Cardiovascular; Disease; Factors; Patient; Psychosocial; Support

\section{Introduction}

Cardiovascular diseases (CVD) are included among the most frequent diseases of civilization (Gielen et al., 2015). In Europe, the mortality due to cardiovascular diseases is different in the EU and the countries outside of it (Wilkins et al., 2017). In the Czech Republic, they are the main cause of death. The total standardized mortality was 42\% in 2016 (ÚZIS ČR, 2016). Despite the differences in the clinical symptoms of these diseases, they share the same cause, which is atherosclerosis. Atherosclerosis is a degenerative illness of the arteries. The causes of atherosclerosis are multifactorial and closely related to lifestyle (Piepoli et al., 2016; Puska et al., 2011). Mortality due to chronic cardiovascular diseases has decreased in the last ten years but the prevalence is still high (Cífková et al., 2010). The incidence of cardiovascular diseases is related to age but it can be etiologically related to other diseases, such as obesity and sleep apnoea syndrome etc. (Slouka et al., 2018a).
The statistics of the Institute of Health Information and Statistics of the Czech Republic show that the number of sick days due to diagnosed CVD increases from 40 years of age, and most sick days are found in people between 60 and 64 and 65+ (ÚZIS ČR, 2016). Cardiovascular diseases and those pathophysiologically related to them are a serious public health problem and an economic burden for society and its healthcare system (Piepoli et al., 2016).

Psychosocial factors became considered health affecting after the relationship between stress and health was found (Solgajová et al., 2015). Contemporarily, we do not question the hypotheses on the relationship between health and low socioeconomic status (SES). People with lower SES are more frequently stressed, which is negatively reflected on the health condition (Callander and McDermott, 2017; Labarthe, 2010). One example is the research of the authors Kajanová et al. (2016), who learned that socially excluded people have a significantly lower overall quality of life (as well as lower physical and mental health). Another example is the study of Slouka

\footnotetext{
* Author for correspondence: Lenka Šedová, University of South Bohemia in České Budějovice, Faculty of Health and Social Sciences, Institute of Nursing, Midwifery and Emergency Care, U Výstaviště 26, 37005 České Budějovice, Czech Republic; e-mail: lsedova@zsf.jcu.cz; http://doi.org/10.32725/kont.2019.028
} 
et al. (2018b), which confirms a more frequent incidence of larynx cancer in people with lower socioeconomic status and unsuitable life habits.

More than 50 years ago, the first evidence of the significance of psychosocial risk factors appeared regarding the incidence of cardiovascular diseases. The related factors specifically include low socioeconomic status, lack of social support, low health literacy, work stress and family life, depression and anxiety, and hostility (Bruthans et al., 2016; Compare et al., 2013; Slouka et al., 2018a). For example, according to the study of Kabátová et al. (2014), depression and bad mood are related to the incidence of chronic illnesses. The respondents most frequently showed cardiovascular diseases.

These factors contribute to the incidence of cardiac ischemic disease and worsen the prognosis for patients with coronary artery disease. They are the factors that affect the incidence of coronary cardiac diseases and can be an obstacle in managing and following the treatment of these diseases (de Mestral and Stringhini, 2017; Töres et al., 2015).

The relationship between unfavourable work conditions and the incidence of CVD has been studied for decades. The mechanisms of the incidence are still unclear and the explanatory theories include direct activations of neuroendocrine reactions to stressors; indirect factors include unhealthy behaviour - smoking, inactivity, obesity or the overconsumption of alcohol (Kivimäki and Kawachi, 2015; Slouka et al., 2018a).

The psychosocial factors also include the level of social support. Social support, which is received from other people, groups and wider society, can affect the way patients manage difficult situations such as illnesses. Social support can be divided into emotional, evaluating, informational and instrumental (Albus, 2010).

The treatment of CVD is not only carried out with medicaments. The non-medicament part of the treatment also plays an important and complex role (Doležal and Jarošová, 2015). This complex treatment includes the bio-psycho-social view of a patient. The anamnesis of psychosocial factors affecting cardiovascular health should become a common part of clinical practice. Learned information should be assessed considering the individual differences of every patient (Slouka et al., 2018b). An individualized approach in treatment offers multimodal interventions which can include a number of other experts, such as nutritional therapists, physiotherapists, psychologists (Albus and Hermann-Lingen, 2015; Buford et al., 2015; Schwarzer, 2008).

In this study, we focused on discovering patients' opinions on selected psychosocial factors which are related to the incidence and development of CVD. We wanted to prove the relationship between the questions regarding psychosocial factors and the selected sociodemographic factors of the sample group.

We focused on finding out about the patients' socioeconomic status as well as their employment. We also focused on questions regarding the impact of lifestyle changes on the patient's life and who supports the changes.

\section{Materials and methods}

We used the combination of a non-standardized questionnaire and the standardized SF-36 questionnaire. The non-standardized questionnaire was designed to assess education. We used it to monitor the education from the point of view of people. We also wanted to estimate how long the health education lasted and to describe the extent and content of the education including barriers.
The field research was carried out using the technique of standardized conducted interview between an interviewer and a respondent (face-to-face). The final form of the interviewer's sheet was based on the pre-research results. The research was anonymous, the participation was voluntary and it did not contain any controversial ethical questions.

The data collection was carried out in 2016. It was secured by 582 professional interviewers from the Institute for the Study of Health and Lifestyle in the Czech Republic.

The statistical processing of the data was carried out using the SASD 1.4.12 (Statistical Analysis of Social Data) programme and SPSS. We processed the 1st classification degree and the contingency tables of the selected indicators of the 2nd classification degree. In the 1st classification degree, calculations of absolute and relative numbers were carried out, as well as the modus, median, average, variance and standard deviation. For every indicator, we carried out the calculation of the variance, standard deviation, margin and interval estimate of the average value 0.05 and the interval variance estimate 0.05 . For the calculation of the level of dependence of selected indicators, we calculated the Wallis-Spearman and correlation coefficient. We also applied the chi-2 of good concordance, where we applied the Yates correction in case of an insufficient number of monitorings. We finally calculated the test of independence on the level of significance $\alpha=0.05 ; \alpha=0.01 ; \alpha=$ 0.001 .

We addressed 2,306 respondents, of which 314 (13.6\%) refused to be included in the study. 1,992 respondents aged 40 and above agreed to the interview. The parameters of the sample group were based on the data from the Czech Statistical Office from the 31st December 2014. The sample group consisted of people from the $\mathrm{Czech}$ Republic and its structure responded to the following criteria: all regions, age and gender. These indicators were set as representative.

\section{Results}

The sample group included 937 men (47\%) and 1,055 (53\%) women, which responds to the analogue structure of the people in the Czech Republic over 40 years. The sample group included the lowest number of respondents over 70 (Table 1 ).

\begin{tabular}{|c|c|c|c|c|}
\hline & \multicolumn{2}{|c|}{ Men } & \multicolumn{2}{|c|}{ Women } \\
\hline & $A$ & $\%$ & $A$ & $\%$ \\
\hline $40-49$ years & 284 & 14.3 & 275 & 13.8 \\
\hline $50-59$ years & 242 & 12.1 & 245 & 12.3 \\
\hline $60-69$ years & 237 & 11.9 & 270 & 13.6 \\
\hline $70-79$ years & 126 & 6.3 & 167 & 8.4 \\
\hline 80 years and above & 48 & 2.4 & 98 & 4.9 \\
\hline Total & 937 & 47 & 1,055 & 53.0 \\
\hline
\end{tabular}

162 (8.1\%) respondents had basic education, 735 (36.9\%) had apprenticeship certificate, 680 (34.1\%) had secondary education, 103 (5.2\%) had higher vocational education and $312(15.7 \%)$ had a university education. The majority of the respondents were married $(1,167 ; 60.1 \%), 129$ (6.5\%) were single, 256 (12.9\%) were divorced, 101 (5.1\%) respondents lived in a partnership and 309 (15.5\%) respondents were wid- 
owed. The majority of the respondents were employees (965; 48.4\%), 211 (10.6\%) ran a business, 674 (33.8\%) were retired, 92 (4.6\%) drew an disability pension and 38 (1.9\%) were unemployed for more than 6 months. 12 (0.6\%) chose the option "other employment".

$47.1 \%$ were treated for cardiovascular disease. Most frequently, they were 50 years old with hypertension, vascular diseases of lower limbs or the condition after heart attack.

The respondents were asked who they saw as the greatest support in the change of their lifestyle. They were offered 6 options - doctor; nurse; friends; family; other patients and somebody else. The respondents gave numbers to every option: 1 = the largest support, and $6=$ the smallest support.

The comparison of average values shows that the largest support is family. A doctor is in second place, friends are in third place, and a nurse is in fourth place. Other patients had the smallest influence. Regarding doctors, there was a greater variability of responses. The smallest was related to other patients (who were in fifth place) (Table2).

Regarding the assessment of the significance of individual subjects as a support in the change of lifestyle, doctors were in the 1 st $(29.3 \%)$ and 3rd place (24.5\%).

$50.0 \%$ of the respondents put family in 1 st place. $21.8 \%$ put it in 2nd place and $15.3 \%$ put it in 3rd place. This fact and the comparison of the average values enable the conclusion that the respondents consider family to be the most important support regarding the change in their lifestyle (Table 2).

The assessment of family as the support for change in lifestyle is significantly related to education $(P<0.05)$. The respondents with basic education and higher vocational education attached significantly lesser importance to the support in the change of lifestyle. Statistically significant connections to other sociodemographic indicators were not identified.

Another question was focused on the patients' opinion about their interest in selected psychosocial factors in medical practice. The results are shown in Chart 1 .

The results show that the respondents say that doctors are interested in their patients' employment and whether their job is physically or psychologically demanding (67.5\%). The results of the statistical significance show that doctors' interest in the effect of their patients' job on their lifestyle is significantly related to the patient's gender, age, education and job. Women more frequently chose a positive response to this question $(p<0.01)$, the younger ones (40-59 years) more frequently agreed with the statement $(p<0.01)$, and so did the employed respondents $(p<0.001)$.

\begin{tabular}{|c|c|c|c|c|c|}
\hline Support & Modus & Median & $\bar{x}$ & $s^{2}$ & $S$ \\
\hline Doctor & 1 & 2 & 2.591 & 1.890 & 1.375 \\
\hline Nurse & 4 & 4 & 3.503 & 1.582 & 1.258 \\
\hline Friends & 2 & 3 & 2.830 & 1.380 & 1.175 \\
\hline Family & 1 & 1 & 1.977 & 1.528 & 1.236 \\
\hline Other patients & 5 & 5 & 4.590 & 1.203 & 1.097 \\
\hline
\end{tabular}

$\bar{x}=$ arithmetic average; $s^{2}=$ variance; $S=$ standard deviation.

Doctors are less interested in their patients' socioeconomic situation. $53.7 \%$ of the respondents chose a negative response to this question. This question showed a significant relationship with the respondents' employment $(p<0.001)$. The employed respondents responded negatively; disabled pensioners and the unemployed responded more positively.

The respondents positively assessed the interest of doctors in their patients' lifestyle (58.7\%) and the way their illness affected their life (58.8\%). We identified a statistically significant relationship between the question of the interest in a patient's lifestyle and gender $(p<0.05)$, age $(p<0.001)$ and employment $(p<0.01)$. Women and the respondents between 40 and 59 years more frequently chose the negative response. Meanwhile, older respondents more frequently chose a positive response. We also identified a statistically significant relationship regarding employment. The employed respondents more frequently responded negatively, in contrast to pensioners who more frequently responded positively. The analysis of the question of how the illness affected the patient's life is significantly related to age $(p<0.001)$, employment $(p<0.001)$, and education $(p<0.001)$. The relationship to age shows that younger respondents (40-59 years) more frequently do not agree with the statement, while older respondents agree with it. The respondents with a lower level of education (basic, apprenticeship) more frequently responded positively. Secondary school and university graduates mostly chose "I do not know". The result shows that a doctor is interested in their patients' present lifestyle if they are familiar with their patient's job. The employed respondents more frequently chose a negative response, while pensioners agreed with the statement.

$44.8 \%$ of the respondents chose a positive response to the question of whether doctors had records on their progress in

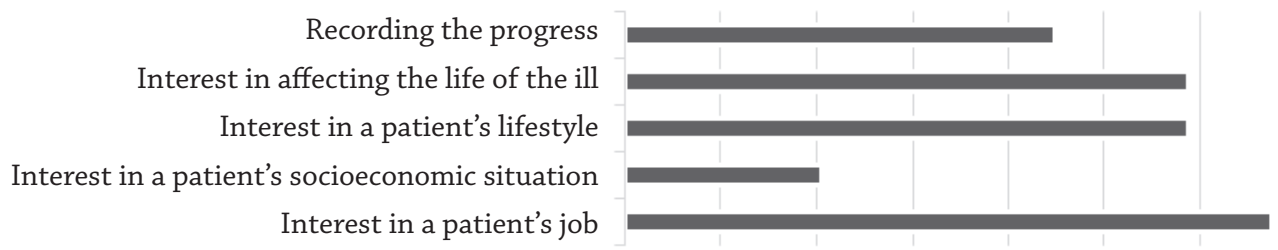

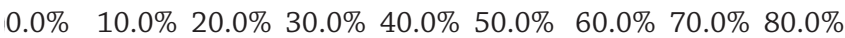

\begin{tabular}{|c|c|c|c|c|c|}
\hline \begin{tabular}{|c|c|c|}
\hline Interest in \\
a patient's \\
job
\end{tabular} & $\begin{array}{c}\text { Interest in a patient's } \\
\text { socioeconomic } \\
\text { situation }\end{array}$ & $\begin{array}{c}\text { Interest in } \\
\text { a patient's } \\
\text { lifestyle }\end{array}$ & $\begin{array}{c}\text { Interest in } \\
\text { affecting the life } \\
\text { of the ill }\end{array}$ & $\begin{array}{c}\text { Recording } \\
\text { the progress }\end{array}$ \\
\hline Patients & $67.5 \%$ & $20.6 \%$ & $58.7 \%$ & $58.8 \%$ & $44.8 \%$ \\
\hline
\end{tabular}

Chart 1. Doctors' interest in the factors that affect the changes in a lifestyle 
changing their lifestyle. More than $1 / 3$ of the respondents did not know of any records. Here as well, we identified the relationships to age $(p<0.001)$, education $(p<0.05)$ and employment $(p<0.001)$. Older respondents, along with those with a lower level of education and pensioners were more frequently positive regarding this question.

\section{Discussion}

The goal of this study was to analyze the level of the selected psychosocial factors, which should be a part of the medical history of patients with cardiovascular diseases. We tried to find the relationship between the respondents' opinions and the selected sociodemographic characteristics.

Psychosocial factors affect the incidence and development of CVD. The consideration of psychosocial factors enables an individualized approach in a complex treatment. As stated by Albus et al. (2015), one alternative for how to achieve a complex treatment in a patient with ischemic cardiac disease is offering multimodal interventions, which are based on the influence of other experts, such as nutritional therapists, physiotherapists or psychologists.

These days, there is a lot of evidence on the causality of the incidence of cardiovascular diseases and influenceable risk factors. In common practice, the behavioural factors of these diseases are not given sufficient attention with regard to the fact that these factors are not a part of common scoring systems for the estimation of cardiovascular diseases.

Psychosocial factors are a part of cardio-prevention despite the fact that the causal effect of these factors on the incidence of cardiovascular diseases has different methodological and conceptual limitations. Psychosocial factors specifically include a low socioeconomic status, insufficient social support, work stress and family life, depression and anxiety, and hostility (Albus, 2010; de Mestral and Stringhini, 2017).

We focused on the issue of a patient's socioeconomic situation and employment, as well as on questions about the impact of the change in the patient's lifestyle on their life and who supports them in achieving the change.

The evidence on the influence of workload on the incidence of CVD is shown by Kivimäki and Kawachi (2015). They bring evidence from 600,000 men and women from 27 cohort studies that were carried out in Europe, the USA and Japan. These studies show that work stress, such as a high level of physical labour and long working hours are related to a medium risk of CVD and stroke. Small differences were recorded in the comparison of men and women, elderly and younger people and employees with a different SES. Only a few studies dealt with practical intervention regarding work stress and its positive effect. Despite this fact, governments started campaigns for health support at workplaces with the focus on the restriction of work stress. The support of the awareness of the relationship between work stress and CVD is an important part of health support. In our research, $67.5 \%$ of the respondents stated that their doctor was interested in their job. In this question, it is interesting that we recorded a relationship to gender. Women responded positively more frequently than men $(p<0.01)$. It is necessary to mention that work anamnesis should be an obligatory part of a patient's total anamnesis. Employment regarding cardiovascular diseases is very important because work in a stressful environment may cause or worsen the condition of CVD. A much worse prognosis is proven in unemployed patients (Töres et al., 2015). In our sample group, the majority of the respondents were employed and only $1.9 \%$ were unemployed for more than 6 months. The question regarding employment is related to the doctor's interest in the patient's socioeconomic situation. According to the respondents, their doctors show little interest in their socioeconomic situation (20.6\%). Here, we can see the relationship between a positive response and employment $(p<0.001)$. The respondents who are employed often responded negatively, which is in contrast to the invalid pensioners or unemployed respondents. Here, it is shown that doctors are interested in the way their patients with low income manage their situation. This question is very important because an employed patient can also have a low income and thus be in a complicated situation which can cause daily stress. Other questions concerned the doctors' interest in the respondents' lifestyle and how CVD affected their life. In both questions, more than $50 \%$ of the respondents responded positively (Chart 1 ). We identified a relationship between the doctors' interest in their patients' lifestyle and gender $(p<$ $0.05)$, age $(p<0.001)$ and job $(p<0.01)$. Men more frequently responded positively, as well as the unemployed respondents, pensioners and older respondents. If we are to provide patients with recommendations regarding changes in their lifestyle, we should know their contemporary lifestyle. $58.7 \%$ of the respondents responded positively to the question regarding their doctor's interest in their current lifestyle, which is not a satisfying result, so we can say that doctors are inclined toward unified recommendations. Another question is related to the doctors' interest in the way CVD affects a patient's life. $58.8 \%$ of the respondents responded positively. Here, we can also say that it is not a high number. Older respondents, unemployed respondents, pensioners or those with a lower level of education more frequently responded positively. We can say that doctors' questions about this issue are directed toward the threatened groups of patients. The question about the influence of CVD on life is related to social support. Social support is one of the most studied factors that moderate the influence of negative life events. A number of studies show that the combination of low social support and long-term stress is a predictor of the incidence of a number of diseases (Compare et al., 2013). In this study, we dealt with the question of who is the largest support in the process of changing the lifestyle of patients with CVD. The results are shown in Table 2 . It is clear that in our sample group the largest support is provided by families, then doctors, friends, nurses and other patients. The analysis of the second classification degree shows that the choice of a doctor, nurse or friends as social support is related to age, employment or marital status. It is clear that doctors, nurses and friends are more frequently considered as support in this issue by the respondents over 60 years and the respondents living alone, those who were widowed and pensioners.

\section{Limitations of the study}

The conclusions can be limited by the random selection of the sample group.

\section{Conclusions}

The conclusions provide evidence of the fact that doctors are focused on gaining information about their patients' employment, lifestyle and the influence of CVD on their life. It is interesting that fewer respondents are interested in the socioeconomic situation, which is related to employment and the effect on lifestyle. Most questions showed a significant relationship between age, employment and marital status. Respondents over 60 years more frequently answered positively, as well as 
those who were widowed and pensioners. This fact can be related to the targeted intervention regarding these threatened groups of patients. Most respondents consider family as support regarding the change in their lifestyle.

\section{Acknowledgements}

Supported by the program project of the Czech Ministry of Health, reg. No. 15-31000A. All rights are reserved according to regulations for protection of intellectual property.

\section{Conflict of interests}

The authors have no conflict of interests to declare.

\section{Sociální opora v edukaci pacientů s kardiovaskulárními chorobami: situace v České republice}

\section{Souhrn}

Výskyt kardiovaskulárních chorob je vázán na rizikové faktory životního stylu. Tradičními ovlivnitelnými faktory jsou kouření, výživa, fyzická aktivita a psychosociální faktory. Mezi psychosociální faktory konkrétně patří nízké socioekonomické postavení, nedostatek sociální opory, pracovní stres a stav nebo způsob rodinného života, deprese a úzkost, nepřátelství.

Cílem předložené studie bylo prokázat souvislost názorů na sledování vybraných psychosociálních faktorů kardiovaskulárních chorob s vybranými sociodemografickými charakteristikami. K naplnění cílů byla využita kvantitativní metoda s využitím řízených rozhovorů. Celkem bylo osloveno 1992 osob ve věku 40 let. Soubor byl reprezentativní věkem, pohlavím i bydlištěm. Zjištěné informace byly podrobeny statistické analýze a míra závislosti byla hodnocena pomocí chí-2 testu, $t$-testu a testu analýzy.

Z výsledků je patrné, že se lékaři v rámci prevence ve své praxi orientují na získání informací o zaměstnání svých pacientů, o životním stylu pacienta i o tom, jak diagnostikované kardiovaskulární onemocnění ovlivňuje běžný život pacientů. Méně často dochází v praxi ke zjištění otázek k socioekonomickým faktorům. Ve většině otázek byla zachycena signifikantní souvislost s věkem, zaměstnáním a rodinným stavem. Kladně na otázky častěji odpovídali respondenti nad 60 let, respondenti ovdovělí a respondenti v invalidním nebo starobním důchodu. Tento fakt může souviset s cílenou intervencí u těchto ohrožených skupin pacientů. Pro většinu respondentů je rodina oporou v úpravě životosprávy.

Klíčová slova: kardiovaskulární; faktory; choroby; pacient; psychosociální; opora

\section{References}

1. Albus C (2010). Psychosocial and social factors in coronary heart disease. Ann Med 42(7): 487-494. DOI: 10.3109/07853890.2010.515605.

2. Albus Ch, Hermann-Lingen Ch (2015). Behaviour and motivation. In: Gielen S, De Backer G, Piepoli M, Wood D (Eds). The ESC textbook of preventive cardiology. Oxford: Oxford University Press, pp. 105-112.

3. Bruthans J, Mayer O Jr, De Bacquer D, De Smedt D, Reiner Z, Kotseva K, et al. (2016). Educational level and risk profile and risk control in patients with coronary heart disease. Eur J Prev Cardiol 23(8): 881-890. DOI: 10.1177/2047487315601078.

4. Buford WT, Anton DS, Bavry AA, Carter CS, Daniels MJ, Pahor M (2015). Multi-modal intervention to reduce cardiovascular risk among hypertensive older adults: Design of a randomized clinical trial. Contemp Clin Trials 43: 237-242. DOI: 10.1016/j.cct.2015.06.019.

5. Callander EJ, McDermott R (2017). Measuring the effects of CVD interventions and studies across socioeconomic groups: A brief review. Int J Cardiol 227: 635-643. DOI: 10.1016/j. ijcard.2016.10.085.

6. Cífková R, Skodová Z, Bruthans J, Adámková J, Jozífová M, Galovcová M, et al. (2010). Longitudinal trends in major cardiovascular risk factors in the $\mathrm{Czech}$ population between 1985 and 2007/8. Czech MONICA and Czech postMONICA. Atherosclerosis 211(2): 676-681. DOI: 10.1016/j. atherosclerosis.2010.04.007.

7. Compare A, Zarbo C, Manzoni GM, Castelnuovo G, Baldassari E, Bonardi A (2013). Social support, depression, and heart disease: a ten year literature review. Front Psychol 4: 384. DOI: 10.3389/ fpsyg.2013.00384.

8. de Mestral C, Stringhini S (2017). Socioeconomic status and cardiovascular disease: an update. Curr Cardiol Rep 19: 115. DOI: 10.1007/s11886-017-0917-z.

9. Doležel J, Jarošová D (2015). Analysis of clinical practice guidelines for cardiovascular disease prevention. Kontakt 17(2): 96-102. DOI: 10.1016/j.kontakt.2015.05.001.

10. Gielen S, Backer De G; Piepoli FM, Wood D (2015). The ESC Textbook of preventive cardiology. Oxford: Oxford University Press.

11. Kabátová O, Uríčková A, Botíková A (2014). Factors affecting the incidence of depression in the elderly. Cent Eur J Nurs Midw 5(3): 105-111. DOI: 10.15452/ CEJNM.2014.05.0004

12. Kajanová A, Urban $D$, Hajduchová $H$ (2016). Závěr, shrnutí, doporučení, intervence. In: Kajanová A et al. (Eds). Sociální determinanty zdraví u obyvatel sociálně vyloučených lokalit žijících v Jihočeském kraji. Praha: NLN, pp. 85-88.

13. Kivimäki M, Kawachi I (2015). Work stress as a risk factor for cardiovascular disease. Curr Cardiol Rep 17(9): 74. DOI: 10.1007/s11886-015-0630-8.

14. Labarthe RD (2010). Epidemiology and prevention of cardiovascular diseases. London: Janes and Barlett Publishers.

15. Piepoli MF, Hoes WH; Agewall S, Albus C, Brotons C, Catapano AL, et al. (2016). European Guidelines on cardiovascular disease prevention in clinical practice: The sixth joint task force of the European society of cardiology and other societies on cardiovascular disease Prevention in Clinical Practice (constituted by representatives of 10 societies and by invited experts). Eur Heart J 37(29): 2315-2381. DOI: 10.1093/ eurheartj/ehw106.

16. Puska P, Norrving Bo, World Health Organization (2011). Global Atlas on cardiovascular disease prevention and control. Geneva: WHO.

17. Schwarzer R (2008). Modeling health behavior change: how to predict and modify the adoption and maintenance of health behaviors. Appl Psychol 57(1): 1-29. DOI: 10.1111/j.14640597.2007.00325.x.

18. Slouka D et al. (2018a). Otorinolaryngologie. Praha: Galén.

19. Slouka D, Kučera R, Hošek P, Gál B, Trčka O, Kostlivý T, Havel D (2018b). Key problems of the quality of life of patients after 
total laryngectomy. Kontakt 20(3): 249-255. DOI: 10.1016/j. kontakt.2018.08.006.

20. Solgajová A, Sollár T, Vörösová G (2015). Gender, age and proactive coping as predictors of coping in patients with limb amputation. Kontakt 17(1): e1-e7. DOI: 10.1016/j. kontakt.2015.01.005

21. Töres T, Brisson Ch, Ouimet GM (2015). Psychosocial factors I the prevention of cardiovascular disease. In: Gielen S, De
Backer G, Piepoli M, Wood D (Eds). The ESC textbook of preventive cardiology. Oxford: Oxford University Press, pp. 238-250.

22. UUZIS ČR (2016). Zdravotnická ročenka České republiky 2016. Praha: ÚZIS ČR.

23. Wilkins E, Wilson L, Wickramasinghe K, Bhatnagar P, Leal J, Luengo-Fernandez R, et al. (2017). European cardiovascular disease statistics 2017. Brussels: European Heart Network. 